\title{
Effectiveness and residue levels of 3 methods of menthol application to honey bee colonies for the control of tracheal mites *
}

\author{
D Nelson 1, P Sporns 2, P Kristiansen ${ }^{3 * *}$, P Mills ${ }^{1}, \mathrm{M} \mathrm{Li} 2$ \\ ${ }^{1}$ Agriculture Canada, Research Station, Beaverlodge, $A B$ TOH OCO; \\ 2 University of Alberta, Dept of Food Science, Edmonton, AB T6G 1P5; \\ 3 Fairview College, Beekeeping Program Fairview, AB Canada TOH $1 \mathrm{LO}$
}

(Received 6 November 1992; accepted 10 March 1993)

\begin{abstract}
Summary - Menthol foam-strips, vegetable shortening-menthol paste containing 30 and $60 \mathrm{~g}$ menthol and melted vegetable shortening-menthol-dipped cardboard $(30 \mathrm{~g})$ were applied to tracheal mite-infested colonies and compared to untreated control colonies. Honey and wax samples from brood frames, honey super frames and from bulk extracted honey were analyzed for menthol residues. The prevalence of mite-infested bees was reduced in all menthol treatments (applied 17 May) to $<1 \%$ by the end of August. The controls increased in tracheal mite prevalence to a $25 \%$ level by the end of August. Sealed brood production was not significantly different among the treatments, although brood mortality was observed in most treatments for a few $d$ after application. Honey production was generally lower in treated colonies and significant differences were evident. Menthol was not detectable in extracted honey or from honey frames in honey supers. Residue levels in brood nest honey were highest in the $60-\mathrm{g}$ foam-strip treatments at $6.2 \mathrm{ppm}$ and were lowest in the $30 \mathrm{~g}$ cardboard treatment at $0.8 \mathrm{ppm}$.
\end{abstract}

Acarapis woodi / chemical control / menthol / honey / residue

\section{INTRODUCTION}

The recent discovery of tracheal mites, Acarapis woodi Rennie (Acari, Tarsonemidae) in Canada has created concern about the impact on honey production, wintering ability and pollinating ability of in- fested colonies. Wintering ability of heavily infested colonies is probably the greatest concern to beekeepers. Otis et al (1986) and Furgala et al (1989) have pointed out the serious damage that can be expected to occur in wintered colonies in northern climates.

* Contribution No BRS 92-11

** Present address: Rookilde, Denmark 
Short-term control of tracheal mites will require the application of chemical treatments. Menthol has received considerable attention and the fumes from crystalline menthol have proven to control A woodi (Herbert et al, 1988 ; Cox et al, 1989 ; Wilson et al, 1990) when temperatures within the colony are high enough to cause evaporation. During cool conditions, or in fall treatments, menthol is not as effective (Moffett et al, 1989). Menthol placement can help increase evaporation, ie placement on the top bars. However, such placement can also result in high temperatures that melt the menthol crystals and cause subsequent running between the frames. Cox et al (1989) evaluated means of increasing the surface area of the menthol as a means to increase evaporative rate at cooler temperatures. Wilson et al (1990) developed and evaluated a menthol-grease board as a way of increasing evaporation rate.

In this paper we compare vegetable shortening-menthol-dipped cardboard to that of a menthol-paste and menthol foamstrips for tracheal mite control under northern climatic conditions. The residual menthol in brood nest honey, honey super honey, extracted honey, and wax was also determined and details are submitted elsewhere.

\section{MATERIALS AND METHODS}

In late April 199144 indoor-wintered colonies were moved to an apiary site located $10 \mathrm{~km}$ southeast of Fairview, Alberta $\left(56^{\circ} 02^{\prime} \mathrm{N}, 118^{\circ}\right.$ $15^{\prime} \mathrm{W}$ ). All colonies consisted of 1 brood chamber and were equalised in bees and brood. On 7 May, bee samples were collected from each colony and 25 bees were analyzed in order to select 30 tracheal mite-infested colonies. The selected colonies were randomly assigned to 6 treatments (5 replicates each). Colonies not selected for the experiment were removed from the apiary site, and selected colonies were ar- ranged in groups of 4 colonies, 2 pairs facing in opposite directions.

The menthol paste was prepared by heating hydrogenated vegetable shortening (Crisco) to $55^{\circ} \mathrm{C}$ and adding L-menthol of equal weight to the liquid. The mixture was then allowed to cool and solidify. The paste mixture was then spread at room temperature onto the v-notched cardboard of a predetermined size to give the specified dosage.

The foam-strips were prepared by melting Lmenthol at $43^{\circ} \mathrm{C}$ and immersing a $1 / 8$-inch thick reticulated polyester urethane foam material (with a $100 \%$ open cell structure and a range of 10-100 pores/linear inch) into liquid menthol. Once the menthol solidified, strips were cut to provide $10 \mathrm{~g}$ of menthol per strip.

The dipped cardboard treatment was prepared by melting equal weights of vegetable shortening and menthol (see menthol-paste preparation) and dipping corrugated cardboard into the liquid until it contained $30 \mathrm{~g}$ menthol. All the menthol formulations were prepared by $\mathrm{Me}$ divet Pharmaceuticals, High River, Alberta.

All treatments were applied to the colonies on 17 May and removed on 7 June (21 d). A second application of treatment $F$ (CR) was made from 11 July to 14 August so that there a treatment during the honey flow period. The treatments were as follows:

Treatment $A$ (CN, no menthol); control.

Treatment $B$ (PS $60 \mathrm{~g}$ ): Menthol paste containing $60 \mathrm{~g}$ menthol was applied to v-notched cardboard material (size $29.5 \times 28.2 \times 0.4 \mathrm{~cm}$ ) placed on the bottom board.

Treatment $C$ ( $F S 60 \mathrm{~g}$ ): Six menthol foamstrips, each containing $10 \mathrm{~g}$ menthol applied to plastic foam material (size: $13.7 \times 7 \times 0.35 \mathrm{~cm}$ ), were placed between the frames near the back and front of the hive. Strips were suspended between frame numbers 2 and 3,5 and 6 , and 8 and 9 in a 9 -frame super.

Treatment $D$ (FS $30 \mathrm{~g}$ ): Three menthol foamstrips each containing $10 \mathrm{~g}$ menthol were applied to plastic foam material (size: $13.7 \times 7 \times$ $0.35 \mathrm{~cm}$ ) and placed between the frames near the back of the hive. Strips were suspended between frame numbers 2 and 3,5 and 6 , and 8 and 9.

Treatment $E$ ( $P S 30 \mathrm{~g}$ ): Menthol paste containing $30 \mathrm{~g}$ menthol was applied to v-notched 
material (size $21.5 \times 21 \times 0.4 \mathrm{~cm}$ ) and placed on the bottom board.

Treatment $F(C R 30 \mathrm{~g})$ : Menthol-dipped cardboard containing $30 \mathrm{~g}$ menthol (size $33.2 \times 28 \times$ $0.45 \mathrm{~cm}$ ) was placed on the bottom board.

\section{General procedures}

Colonies were fed a non-medicated 2:1 sugar syrup in frame-feeders on 8 and 25 May, and on 13 June. Terramycin in icing sugar was dusted across the top bars of each colony on 23 May and 7 June. Queen and disease checks were carried out regularly ( $\approx$ every 10-14 d) throughout the season. On 30 May a second brood chamber was placed on each hive. On 29 June the brood chambers were reversed (the positions of the bottom and top brood chambers were exchanged) frame feeders removed and 2 honey supers were placed on each colony.

Throughout July honey supers were added to the colonies as required. Honey was removed twice: on 22 July with the abandon (tip-off) method and on 15 August with the aid of a beeblower. After the last honey was removed 1 super was put on each hive; but no more honey was produced. These supers were removed again on 28 August.

\section{Bee samples}

Approximately 100 bees were taken from hives to determine mite prevalence in colonies on: a) 7 May (colony selection); b) 16 May (pretreatment); and c) 21 June and 22 August (posttreatment). The number of bees dissected for each colony for each sampling period was 25 in (a) and 50 in (b) and (c).

\section{Brood measurement}

Sealed brood was measured by placing a piece of clear acrylic plastic with an inscribed grid ( $1 \mathrm{x}$ 1 in) over the sealed brood prior to treatment application (15 May) and $14 \mathrm{~d}$ after treatments had been discontinued (20 June) to determine colony development. Honey production was determined by weighing each super before putting it on the hive and after removal.

\section{Temperature monitoring in colonies}

From 17 May through 11 July temperature was monitored by a data logger (Campbell Scientific model CR10 and an AM32 Multiplexer) in 2 colonies of each treatment. Copper-constantan thermocouples were placed on the bottom board and on the top of the frames of the brood chamber. When colonies received the second brood chamber, the thermocouple remained on top of the frames next to the lid. All hives were equipped with wooden insulated lids with plywood tops. Ambient temperature and precipitation were also monitored.

\section{Honey and wax samples}

Honey from the brood chamber and honey supers as well as extracted honey were sampled for residue analysis. For background analyses, 1 frame from the brood chamber was removed from 1 hive in each treatment before treatments started on 17 May. On 7 June and 11 July, 1 frame from the brood chamber was removed from each of 2 colonies in each treatment. On 11 July and 14 August, 1 frame was removed from the honey super just above the queen excluder. On 14 August, 1 frame from the brood chamber was removed from 2 hives in treatments $A$ and $F$. All frames selected were near the outside of the brood nest, were coded and put in plastic bags in the apiary, then frozen before shipment to the University of Alberta for analysis.

Extracted honey samples were taken for analysis from bulk honey collected from menthol-treated colonies. Honey and wax samples were steam distilled and hexane extracted, dried and injected into a capillary gas chromatograph. The detailed methods and results appear in another paper (Li et al, 1992).

\section{Data analysis}

The brood and honey production data were analyzed by the General Linear Model of SAS in an analysis of variance (SAS institute 1985) and the least significant difference (LSD) to separate differences between treatment means. 


\section{RESULTS}

\section{Honey bee tracheal mite levels}

Tracheal mite prevalence for the 4 time periods of sampling; colony selection ( 7 May), pre-treatment (16 May) and posttreatment (21 June and 22 August) periods are shown in figure 1 . The mite prevalence for the control increased throughout the summer, whereas all menthol treatments showed reduced tracheal mite prevalence. By August the mite prevalence (number of mite infested bees) in all treated colonies was reduced to $<1 \%$, whereas in the control it had increased to $25.6 \%$ from an initial average of $\approx 12 \%$.

\section{Sealed brood and honey production}

Sealed brood measurements and honey production are shown in table I. Colony development as indicated by sealed brood did not show significant differences be-
BEES INFESTED WITH TRACHEAL MITES

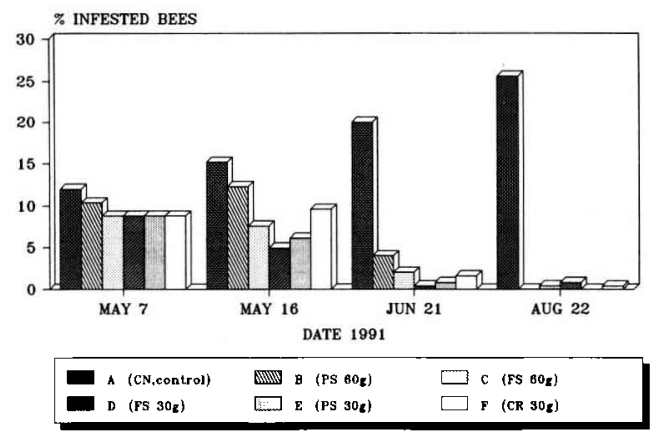

Menthol applied May it

Fig 1. Percent tracheal mite-infested bees before and after menthol treatments.

tween treatments. However, there was an indication of suppressed brood-rearing with treatments $C$ (FS $60 \mathrm{~g}$ ) and F (CR 30 g). The honey production of these 2 treatments was also the lowest.

The control colonies developed normally with eggs and brood in all stages. How-

Table I. Mean sealed brood area prior to menthol application (15 May) and $14 \mathrm{~d}$ after menthol application (20 June) and honey production.

\begin{tabular}{llll}
\hline Treatment & \multicolumn{2}{c}{ Sealed brood area $\left(\mathrm{in}^{2}\right)$} & $\begin{array}{l}\text { Honey production } \\
\text { (kg/colony) }\end{array}$ \\
\cline { 2 - 3 } & 15 May & 20 June & \\
\hline A (Control) & $256 \pm 32^{\star a}$ & $461 \pm 80^{\mathrm{a}}$ & $62 \pm 12^{\mathrm{a}}$ \\
B (PS 60 g) & $292 \pm 37^{\mathrm{a}}$ & $457 \pm 80^{\mathrm{a}}$ & $54 \pm 11^{\mathrm{ab}}$ \\
C (FS 60 g) & $261 \pm 33^{\mathrm{a}}$ & $326 \pm 57^{\mathrm{a}}$ & $29 \pm 6^{\mathrm{c}}$ \\
D (FS 30 g) & $299 \pm 38^{\mathrm{a}}$ & $503 \pm 88^{\mathrm{a}}$ & $64 \pm 13^{\mathrm{a}}$ \\
E (PS 30 g) & $296 \pm 37^{\mathrm{a}}$ & $471 \pm 82^{\mathrm{a}}$ & $51 \pm 10^{\mathrm{abc}}$ \\
F (CR 30 g) & $327 \pm 41^{\mathrm{a}}$ & $371 \pm 65^{\mathrm{a}}$ & $32 \pm 6^{\mathrm{bc}}$ \\
Mean & 288 & 432 & 49 \\
\hline
\end{tabular}

* Mean \pm SE. Means in columns followed by the same letter are not significantly different $(P<0.05) ;{ }^{* *} \mathrm{PS} 60 \mathrm{~g}: 60 \mathrm{~g}$ menthol paste; PS $30 \mathrm{~g}: 30 \mathrm{~g}$ menthol paste; FS $60 \mathrm{~g}: 60 \mathrm{~g}$ menthol in foam-strip; FS $30 \mathrm{~g}: 30 \mathrm{~g}$ menthol in foam strip; CR $30 \mathrm{~g}: 30 \mathrm{~g}$ menthol in cardboard. 
ever, during the first few $d$ after menthol application, bees in treatments $B$ (PS, $60 \mathrm{~g}$ ) and $E$ (PS, $30 \mathrm{~g}$ ) moved away from the bottoms of the frames and dead pupae were found in front of the colonies and on the landing boards. Dead pupae lying on the paste board were not removed by the bees and a high number of bees were observed fanning at the entrance. In treatment C (FS $60 \mathrm{~g}$ ) and D (FS $30 \mathrm{~g}$ ) the bees moved away from the strips. Cells around the strips were left empty and very little open brood was observed during the treatment period. In treatment $F$, open brood was observed during the treatment period, although not as much as in $A$ and fanning did not appear to be excessive.

Colonies in treatments $\mathrm{B}, \mathrm{C}, \mathrm{D}$ and $\mathrm{E}$ did not resume normal brood rearing until the menthol was removed. However, while the brood measurement on 20 June shows variability, no significant differences occurred.

\section{Residual levels in honey}

Residual levels of menthol in honey from brood chambers were highest in foam- strips $21 \mathrm{~d}$ after application (9.7 ppm) and were much lower $55 \mathrm{~d}$ after application (0.58 ppm) (table II). No menthol residues were found in extracted (bulk) honey. Residue levels in wax were at least 10-fold higher than in honey (Li et al, 1992). The variability and elevated levels of menthol in honey from colonies treated with foamstrips are probably indicative of the strips being in contact with the combs, the bees tracking over the strips and some samples being taken in close proximity to the location of the strips.

\section{Temperature monitoring}

On 2 June a frost occurred and over the test period there was a total of $77.5 \mathrm{~mm}$ precipitation (fig 2).

Comparison of the temperatures of the control (A) and the 60-g menthol paste treatment $(B)$ indicate the repellent nature of menthol. Reduced temperatures indicate the bees (the cluster) move away from the paste treatment when it was placed on the bottom board (fig 3). Thus the repellent nature of menthol probably restricted the brood rearing area available to the colony.

Table II. Menthol residue (ppm) in honey from brood and honey sugars.

\begin{tabular}{llll}
\hline Treatment & $\begin{array}{l}\text { Broodnest } \\
(7 \text { June) }\end{array}$ & $\begin{array}{l}\text { Broodnest } \\
(11 \text { July) }\end{array}$ & $\begin{array}{l}\text { Honey supers } \\
\text { (14 August) }\end{array}$ \\
\hline A (Control) & ND a (6) $^{\mathrm{b}}$ & ND (2) & ND (4) \\
B (PS 60 g) & $1.73(3)$ & $0.25(4)$ & ND (5) \\
C (FS 60 g) & $6.20(4)$ & $0.58(4)$ & ND (6) \\
D (FS 30 g) & $9.70(8)$ & $0.45(4)$ & ND (5) \\
E (PS 30 g) & $1.25(4)$ & $0.05(4)$ & ND (6) \\
F (CR 30 g) & $0.82(5)$ & $0.58(4)$ & $0.08(6)$ \\
\hline
\end{tabular}

a ND: not detectable ; ${ }^{\mathrm{b}}(\mathrm{N})$ number of samples; c PS $60 \mathrm{~g}: 60 \mathrm{~g}$ menthol paste; PS $30 \mathrm{~g}: 30 \mathrm{~g}$ menthol paste; FS $60 \mathrm{~g}: 60 \mathrm{~g}$ menthol in foam-strip; FS $30 \mathrm{~g}: 30 \mathrm{~g}$ menthol in foam-strip; CR $30 \mathrm{~g}: 30 \mathrm{~g}$ menthol in cardboard. 
CLIMATIC RECORD

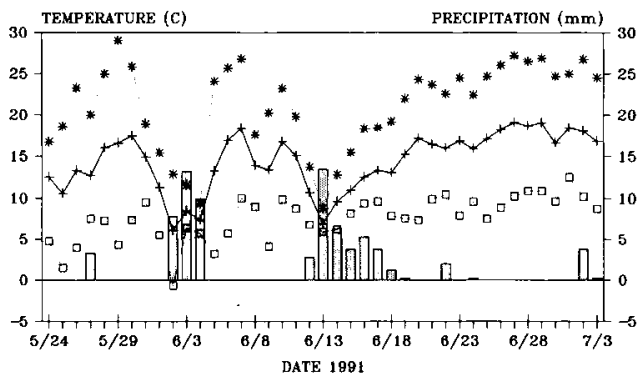

$\rightarrow$ MEAN * MAXIMUM $\square$ MINIMUM $\square$ PRECIP.

Fig 2. Temperature and precipitation data for the test period.

CONTROL VS MENTHOL PASTE $(60 \mathrm{~g})$
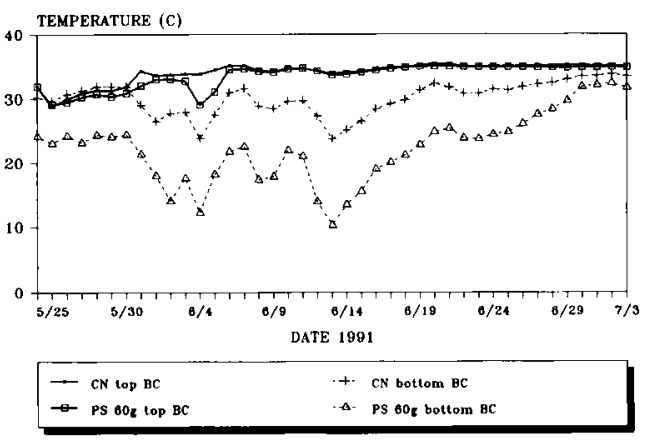

$\mathrm{BC}=$ brood chamber

Fig 3. Temperature data at 2 locations within a colony for the control- $(\mathrm{CN})$ and menthol-paste(PS $60 \mathrm{~g}$ ) treated colonies.

\section{DISCUSSION}

The different menthol treatments used were approximately equally effective for the control of tracheal mites. It was obvious that for treatments $B, C, D$ and $E$ the rate of evaporation was high enough to repel the bees from the area after treatment application. Dead pupae were observed on the bottom board or in front of colonies during the early part of the treatment period. Brood measurements at $14 \mathrm{~d}$ after treatment removal did not show a significant treatment effect. Honey production did show significant differences, which may reflect pupa loss and reduced brood rearing during the application period. These problems may be justified if effective control of the tracheal mite can be achieved. It may be that less menthol could be effective with less impact. The paste formulation and its application to grooved cardboard of a predetermined size has the advantages of easy application and insertion into the colony. The foam strips, although a good means of obtaining evaporation, have the disadvantages of being in contact with the combs, allowing menthol to be tracked across the combs, and they were not easily inserted between the frames.

Treatment $(F)$ received menthol twice during the experiment; one of these was during the honey flow period and some residue was detected in honey from the honey super samples $(0.08 \mathrm{ppm})$. However, menthol as a food additive is often found at levels $>1000 \mathrm{ppm}$ in some products and is not harmful to human health. Menthol cannot be tasted by most people until at least $30 \mathrm{ppm}$ are present ( $\mathrm{Li}$ et al, 1992).

Menthol was approved in Canada (April 1992) for the control of the tracheal mites (Acarapis woodi) in honey bee colonies.

\section{ACKNOWLEDGMENTS}

The authors wish to thank $A$ Sarling and $D$ McKenna, Fairview College; W Baumgartner and $A$ Hatoum, Medivet Pharmaceuticals; and $M$ Kowalchuk and B Mungall, Beaverlodge Research Station, for their in valuable help with this project. The project was made possible by funding to $P$ Sporns and $D$ Nelson via an Alberta Farming for the Future Grant (No 91-0928). 
Résumé - Efficacité de 3 méthodes d'application du menthol pour lutter contre Acarapis woodi Rennie et niveau des résidus dans le miel. À partir du 17 mai et pendant $21 \mathrm{j}$, on a administré à des colonies infestées par l'acarien des trachées (Acarapis woodi) l'une des préparations suivantes au menthol : 1) des bandelettes en mousse à $10 \mathrm{~g}$ de menthol (FS), 2) de la pâte au menthol (PS) à 30 et $60 \mathrm{~g}$ de menthol et 3) du carton imprégné de $30 \mathrm{~g}$ de menthol fondu (CB). Des colonies non traitées (CN) ont servi de témoin. Pour qu'une application ait lieu pendant la miellée, le traitement a été administré une seconde fois du 11 juillet au 14 août. On a analysé les résidus de menthol dans des échantillons de miel et de cire provenant des rayons à couvain, des cadres de hausses et du miel extrait. Du 17 mai au 11 juillet la température a été suivie par un enregistreur dans 2 colonies pour chaque traitement. Des thermocouples cuivreconstantan ont été placés sur le plancher de la ruche et sur le dessus des cadres du corps de ruche. La température ambiante et les précipitations ont été également enregistrées. Le taux d'infestation des abeilles au cours des 4 périodes d'échantillonnage (sélection des colonies 7 mai, prétraitement 16 mai et post-traitements 21 juin et 22 août) a été réduit par tous les traitements à moins de $1 \%$ à la fin d'août (fig 1). Chez les témoins il a atteint $25 \%$. Le type de traitement n'a pas influencé de manière significative la production de couvain operculé, bien qu'une mortalité de couvain ait été observée pendant quelques jours après le traitement pour chaque type de traitement. La production de miel a été généralement plus faible dans les colonies traitées et les différences sont significatives (tableau 1). Le diagramme climatique (fig 2) montre de la gelée le 2 juin "et des précipitations de $77,5 \mathrm{~mm}$ pendant la période de test. La comparaison des températures des colonies témoins et des colo- nies traitées avec la pâte à $60 \mathrm{~g}$ de menthol (PS à $60 \mathrm{~g}$ ) indiquent un effet répulsif du menthol (fig 3). Une baisse des températures indique que les abeilles se sont éloignées de la pâte lorsqu'elle était posée sur le plancher. On n'a pas détecté de menthol dans le miel extrait ni dans celui des hausses. Le niveau des résidus dans le miel du nid à couvain a été le plus élevé avec le traitement FS à $60 \mathrm{~g}(6,2 \mathrm{ppm})$ et le plus faible avec le traitement $C B$ à $30 \mathrm{~g}$ (0,8 ppm) (tableau II).

Acarapis woodi / lutte chimique / menthol / miel / résidu

Zusammenfassung - Wirkungsgrad und Höhe der Rückstände bei drei verschiedenen Ausbringungs-methoden von Menthol in Bienenvölkern zur Bekämpfung der Tracheenmilbe. Beginnend mit dem 17 Mai wurden von Tracheenmilben befallene Bienenvölker für 21 Tage mit folgenden Mentholpräparaten behandelt:

1. Menthol-Schaumstoffstreifen (FS) ;

2. Menthol-Paste mit 30 und $60 \mathrm{~g}$ Menthol (PS) ;

3. Kartonstreifen, getränkt mit geschmolzenem Menthol (30 g), (CB).

Als Kontrolle dienten unbehandelte Völker (CN).

Bei Versuchsansatz (F) erfolgte eine zweite Behandlung von 11 Juli bis zum 14 August, um eine Behandlung auch während der Tracht durchzuführen. Honig-und Wachsproben aus Brutwaben, Waben aus dem Honigraum und aus dem Schleuderhonig wurden auf Mentholrückstände untersucht.

Zwischen 17 Mai bis 11 Juli wurde die Temperatur in je zwei Völkern eines jeden Versuchsansatzes mittels eines Registrierapparates protokoliert. Kupfer-KonstantanTemperaturmeßstellen wurden am Boden- 
brett und über den Rähmchen des Brutraumes angebracht. Außerdem wurden die Außentemperatur und die Niederschläge gemessen.

Bis Ende August war die Häufigkeit milbenbefallener Bienen bei allen MentholVersuchsansätzen auf weniger als $1 \%$ reduziert (Abb 1). Proben wurden zum Zeitpunkt der Auswahl der Völker, am 7 Mai entnommen; ferner vor der Behandlung, 16 Mai; und nach der Behandlung, am 21 Juni und 22 August. Bei den Kontrollen war die Häufigkeit des Milbenbefalls bis Ende August auf 25\% gestiegen. Die Brutmortalität war zwischen den Behandlungsarten nicht signifikant verschieden, aber bei den meisten Versuchsansätzen wurde für einige Tage nach der Ausbringung eine gewisse Brutmortalität festgestellt. Die Honigproduktion war bei den behandelten Völkern allgemein niedriger; die Unterschiede waren signifikant (Tabelle I).

Eine Übersicht über die klimatischen Verhältnisse (Abb 2) zeigt am 2 Juni Frost, und eine Gesamtniederschlagsmenge während der gesamten Versuchsperiode von $77.5 \mathrm{~mm}$. Ein Vergleich der Temperaturen der Kontrollen ( $\mathrm{CN}$ ) mit den Völkern mit Mentholpaste $60 \mathrm{~g}$ (PS 60) zeigt eine Repellentwirkung von Menthol (Abb 3). Niedrigere Temperaturen weisen darauf hin, daß sich die Bienen von der Paste am Bodenbrett zurückziehen.

Weder im Schleuderhonig noch im Honig aus Waben im Honigraum wurde Menthol gefunden. Die Rückstände im Honig aus dem Brutraum, mit Schaumstoffstreifen-Behandlung, waren am höchsten $(6.2 \mathrm{ppm})$, diejenigen nach Behand- lung mit Wellpappestreifen am niedrigsten (0.8 ppm; Tabelle II).

\section{Acarapis woodi / Menthol / Rückstände / Honig / chemische Bekämpfung}

\section{REFERENCES}

Cox RL, Moffett JO, Wilson WT (1989) Techniques for increasing the evaporation rate of menthol when treating honey bee colonies for the control of tracheal mites. Am Bee J $129,129-131$

Furgala B, Duff S, Aboulfaraj S, Ragsdale D, Hyser R (1989) Some effects of the honey bee tracheal mite (Acarapis woodi Rennie) on non-migratory, wintering honey bee (Apis mellifera) colonies in eastern Minnesota. Am Bee J 129, 195-197

Herbert EW, Shimanuki $S$, Matthenius JC (1988) An evaluation of menthol placement in hives of honey bees for the control of Acarapis woodi. Am Bee J 128, 185-187

Li M, Nelson D, Spoams P (1993) Analysis of menthol in honey and wax. $J A O A C$ int (in press)

Moffett JO, Cox RL, Ellis M, Rivera R, Wilson WT, Cardoso TD, Vargas CJ (1989) Menthol reduces winter populations of tracheal mites, Acarapis woodi, in honey bees in Mexico and Nebraska. Southwest Entomol 14, 57-65

Otis GW, Grant G, Randall D, Bath J (1986) Summary of the Tracheal mite project in New York. In: Proc Honey Bee Tracheal Mite Symp. St Paul, MN, July 8-9, 1986

SAS Institute (1985) SAS User's Guide: Statistics. SAS Institute, Cary, NC

Wilson WT, Cox RL, Moffett JO (1990) Mentholgrease board: a new method of administering menthol to honey bee colonies. Am Bee J $130,409-412$ 